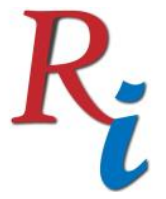

Asia Proceedings of Social Sciences

(APSS)

www.readersinsight.net/APSS

\title{
INTEGRATION OF MUSLIM CEMETERY AND RECREATIONAL AREAS: ANALYSIS OF PLANNING GUIDELINES AND SOCIAL ASPECTS
}

\section{Putri Haryati Ibrahim}

Assistant Professor, Department of Landscape Architecture, Kulliyyah of Architecture and Environmental Design,

International Islamic University Malaysia

Malaysia

putri@iium.edu.my

\section{Mohamad Reza Mohamed Afla*}

Senior Lecturer, Cluster of Urban and Regional Planning, School of Housing, Building and Planning, Universiti Sains Malaysia

Malaysia

rezafla@usm.edu.my

\section{Azila Ahmad Sarkawi}

Associate Professor, Department of Urban and Regional Planning, Kulliyyah of Architecture and Environmental Design,

International Islamic University Malaysia

Malaysia

azila@iium.edu.my

*Corrosponding author's Email: rezafla@usm.edu.my

Peer-review under responsibility of 5th ${ }^{d}$ Asia International Conference 2019 Scientific Committee http://connectingasia.org/scientific-committee/

(C) 2019 Published by Readers Insight Publisher, lat 306 Savoy Residencia, Block 3 F11/1,44000 Islamabad. Pakistan,

editor@readersinsight.net

This is an open access article under the CC BY-NC-ND license (http://creativecommons.org/licenses/by-nc-nd/4.0/). 


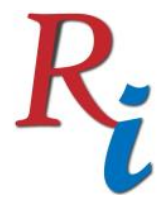

Asia Proceedings of Social Sciences

(APSS)

www.readersinsight.net/APSS

\section{A b s tract}

Recent studies suggested cemetery to be a dual function to accommodate the needs of open spaces that are gradually diminishing. In Malaysia, the Planning Guidelines for Muslim and Non-Muslim Cemetery need to be referred in developing a burial site because a cemetery is an important social infrastructure in the same way to a recreational park. The focus of this research is to analyze the identification of cemetery as an alternative space for social activities that are compatible with the sanctity of Muslim cemetery. This study attempts to reveal how Muslim cemeteries that are often considered as a dead space can be integrated as part of the city's recreational park without marginalizing the spiritual values of the space. The methodology employed comprises of (i) comparative analysis on the contents of the cemetery and recreational planning guidelines, and (ii) site observation of the selected case studies as a mean of data collection. The finding exhibits summative points extracted from both the planning guidelines and the physical elements observed that could transform and revolutionized Muslim cemeteries beyond its norm. This article concludes by providing some recommendations that will help to align the planning and design practice of Muslim cemeteries for future development.

\section{Research High Iights}

Urban areas are experiencing serious land shortages for other types of land uses that also equally important besides residential and commercial uses such as burial grounds and open spaces for recreational activities. Due to shortage of open spaces experienced by many cities around world, the study believes that cemeteries can provide an alternative as a recreational area for urban dwellers. Based on detail content analysis conducted, the study extracted contents related to space planning, facilities, landscape elements and activities that is essential and important to initiate the concept of hybrid cemeteries with a dual function (a burial ground and a recreational area).

At the moment, the link between Muslim communities with their burial spaces is barely realized in Malaysia. The social aspect associated with Muslim cemeteries could be expanded to non-related burial activities to benefits the kariah members. In a manner similar to urban 


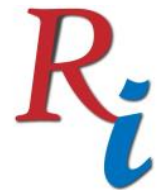

\section{Asia Proceedings of Social Sciences}

(APSS)

www.readersinsight.net/APSS

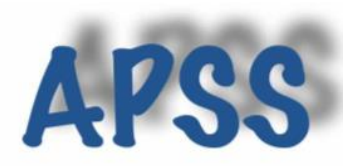

parks, cemeteries should be more open, even contributing to the sense of belonging shared by members of a given community.

\section{Research Objectives}

The study investigated the possibility of integrating cemetery and recreational areas into one functional space that can benefits urban dwellers since land scarcity is experience in many cities around the world. Thus, the study is looking at factors and conditions that could help to reinforce the social function and recreational values of Muslim cemeteries. The aim of this paper is to analyze existing planning guidelines on the integration of Muslim cemetery and recreational areas. In order to achieve the aim three objectives were outlined:

1. to examine both the existing guidelines for cemetery and recreation in Malaysia

2. to identify recreational activities that are compatible with the sanctity of Muslim cemetery

3. to identify the physical design elements that link to the social aspects within Muslim cemetery

\section{Methodology}

The methodology employed in this study is based on qualitative methods which comprise of comparative analysis. It can be divided into (2) two parts as followed:

1. Examine the planning guidelines of present guidelines related to recreation and cemetery planning in Malaysia.

2. Site observation on the connection between social aspects and recreational use at Muslim cemeteries.

\section{Content Analysis}

The study has identified four (4) existing guidelines related to cemetery and recreational planning in Malaysia namely; Planning Guidelines for Muslim and Non-Muslim Cemetery (1997), National Landscape Guidelines (2008), Muslim Cemetery Management Guidelines from the Federal Territory Islamic Affairs Department (JAWI) and Planning Standards and Guidelines for Open Space and Recreation (2000). The analysis conducted was focusing on the 


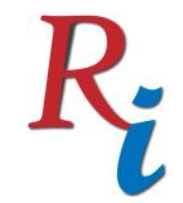

Asia Proceedings of Social Sciences

(APSS)

www.readersinsight.net/APSS

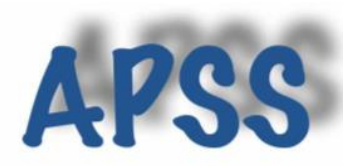

aspects of space planning, facilities, landscape elements and activities that can be conducted at the cemetery and recreational areas in Malaysia.

\section{Case Studies Analysis}

Three (3) existing case studies have been selected namely Section 9 Muslim Cemetery (S9MC), Kuala Lumpur-Karak Cemetery (KLKMC) and Taman Selatan Muslim Cemetery (TSMC). Site observation was conducted in early 2019 based on the checklist consisting of two main components of social aspect at Muslim cemeteries which are spatial planning and facilities. Each component can be divided into two categories of indoor and outdoor spaces.

\section{Results}

The definition of 'open space' in the Town and Country Planning Act 1976 (Act 172) highlighted; open spaces must be accessible for all people to conduct various recreational activities.Thus, in order to revolutionize Muslim cemeteries to be multi-function and adapting with a contested urban condition, the area must be open to all. Currently, most of new and wellplanned Muslim cemeteries are enclosed and guarded. The same phenomenon has been observed in all the case studies conducted. This will be contradicted with the definition of open space in Act 172. Thus, this improvement should be made in present guidelines if the concept of dual function is to be realized for Muslim cemeteries soon. Based on the content analysis of conducted on present guidelines related to recreational and cemetery planning, the study found that there are possibilities to integrate the usage of Muslim cemetery as recreational areas. The finding shows spatial planning and design elements provided can accommodate Muslim cemeteries beyond its cultural norm.

\section{Findings}

Circumstances and times have changed and some of the existing guidelines set out are no longer applicable to be implemented. These policies only touch on the external aspect of a burial ground and does not emphasize the concept of cemetery as part of social identity such as the provision of funeral services to attract visitors and pay homage to the deceased. In order to realize such activities, this study believes that it is essential to provide specific need spaces such as placement of death-related departments such as khairat or funeral expenses and 


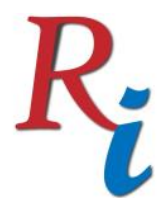

Asia Proceedings of Social Sciences

(APSS)

www.readersinsight.net/APSS

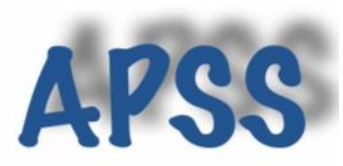

insurance at the cemetery. This indirectly enhances the function of burial grounds to a greater extent not only to a place to bury the dead but also to reminds the living of the dead. Although open spaces may be different in sizes and usage, most importantly, open spaces must be accessible for all people to conduct various recreational activities. Due to the shortage of open spaces available for recreational purposes especially in urban areas, the study found that there are possibilities to integrate recreational and cemetery planning. Size and function of open space can influence potential types of recreational activities conducted. Contemplating, sitting and reading are among the passive activities that use less space. On top of that, the study believes that passive recreational activities like walking or strolling is compatible with the sanctity of Muslim cemetery and can be conducted at cemetery areas because the activities encourage users to find solace and admire God's gift and creation.

\section{Acknowledgement}

This research work is supported by Fundamental Research Grant Scheme (FRGS/1/2018/SSI11/USM/03/4)

\section{References}

Barrett, G. W., \& Barrett, T. L. (2001). Cemeteries as Repositories of Natural and Cultural Diversity. Conservation Biology, 15(6), 1820-1824. doi:10.1046/j.15231739.2001.00410.x

Basmajian, C., \& Coutts, C. (2010). Planning for the Disposal of the Dead. Journal of the American Planning Association, 76(3), 305-317. doi:10.1080/01944361003791913

Bennett, G., \& Davies, P. J. (2015). Urban cemetery planning and the conflicting role of local and regional interests. Land Use Policy, 42, 450-459. doi:https://doi.org/10.1016/j.landusepol.2014.08.011

Bougas, W. A. (1988). Islamic Cemeteries in Patani. Kuala Lumpur: The Malaysian Historical Society.

Clayden, A., Green, T., Hockey, J., \& Powell, M. (2017). Cutting the lawn - Natural burial and its contribution to the delivery of ecosystem services in urban cemeteries. Urban Forestry \& Urban Greening. doi:https://doi.org/10.1016/j.ufug.2017.08.012 


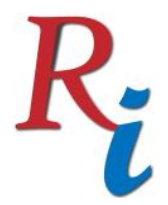

\section{Asia Proceedings of Social Sciences}

(APSS)

www.readersinsight.net/APSS

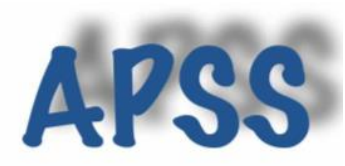

Coutts, C., Basmajian, C., \& Chapin, T. (2011). Projecting landscapes of death. Landscape and Urban

Planning,

102(4),

254-261.

doi:https://doi.org/10.1016/j.landurbplan.2011.05.005

Davies, P. J., \& Bennett, G. (2016). Planning, provision and perpetuity of deathscapes -Past and future trends and the impact for city planners. Land Use Policy, 55, 98-107. doi:https://doi.org/10.1016/j.landusepol.2016.03.029

(JAWI) Federal Territory Islamic Affairs Department. (2019a). Penanaman pokok buahbuahan di tanah perkuburan. Retrieved from http://www.epusara.jawi.gov.my/epusara/webV5/content/127

(JAWI) Federal Territory Islamic Affairs Department. (2019b). Pentadbiran dan pengurusan tanah perkuburan Islam Wilayah Persekutuan. Retrieved from http://www.epusara.jawi.gov.my/epusara/webV5/index.php

(JLN) National Landscape Department. (2008). National Landscape Guidelines. Kuala Lumpur

(JPBD) Department of Town and Country Planning. (1976). Town and Country Planning Act, Act 172. International Law Book Services, Malaysia

(JPBD) Department of town and Country Planning. (1997). Planning Guidelines for Muslim and Non-Muslim Cemetery. Peninsular Malaysia, Kuala Lumpur

(JPBD) Department of town and Country Planning. (2005). Garis Panduan Piawaian Perancangan Tanah Lapang dan Rekreasi (JPBD 7/2000). Peninsular Malaysia, Kuala Lumpur

Henderson, J. C. (2012). The loss of a Cultural Heritage and Tourism Resource: Singapore s Disappearing Burial Grounds. South Asia Journal of Tourism and Heritage, 5(2), 1-14.

Huang, S.-C. L. (2007). Intentions for the recreational use of public landscaped cemeteries in Taiwan. Landscape Research, 32(2), 207-223. doi:10.1080/01426390701231614

Hunt, E. (2019). In Jakarta's cemeteries they're stacking the dead six-deep. The Guardian.

Kenyon Henderson, K., \& Song, Y. (2008). Can nearby open spaces substitute for the size of a property owner's private yard? International Journal of Housing Markets and Analysis, $1(2), 147-165$.

Klaufus, C. (2014). Deathscapes in Latin America's Metropolises: Urban Land Use, Funerary Transformations, and Daily Inconveniences. Revista Europea de Estudios 


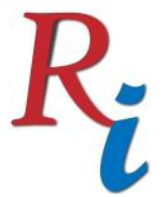

\section{Asia Proceedings of Social Sciences}

(APSS)

www.readersinsight.net/APSS

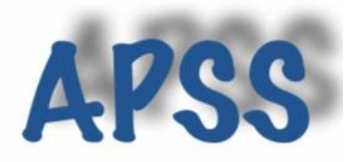

Latinoamericanos y del Caribe / European Review of Latin American and Caribbean Studies(96), 99-111.

Klaufus, C. (2018). Colombian deathscapes: Social practices and policy responses. Journal of Urban Affairs, 40(2), 209-225. doi:10.1080/07352166.2017.1319220

Kowarik, I., Buchholz, S., von der Lippe, M., \& Seitz, B. (2016). Biodiversity functions of urban cemeteries: Evidence from one of the largest Jewish cemeteries in Europe. Urban Forestry \& Urban Greening, 19, 68-78. doi:https://doi.org/10.1016/j.ufug.2016.06.023

Mansor, M., Said, I., \& Mohamad, I. (2012). Experiential Contacts with Green Infrastructure's Diversity and Well-being of Urban Community. Procedia - Social and Behavioral Sciences, 49, 257-267. doi:https://doi.org/10.1016/j.sbspro.2012.07.024

Md Dali, M. (1998). Persepsi terhadap kawasan lapang dan relevansinya dalam masyarakat kini. In M. R. Agus (Ed.), Pembangunan sosial dan ekonomi di Malaysia (pp. 180-189). Kuala Lumpur: Jabatan Antropologi dan Sosiologi, Universiti Malaya.

Md Dali, M. (2003). Development of Kuala Lumpur Urban Parks: The Past and Its Present. Sejarah: Journal of the Department of History, 11(11). doi:10.22452/sejarah.vol11no11.6

Mohamed Afla, M. R. (2012). Sustainability of Urban Cemeteries and the Transformation of Malay Burial Practices in Kuala Lumpur Metropolitan Region. Paper presented at the World Academy of Science, Engineering and Technology, United States.

P. Harnik, A. M. (2010, December 2010). Cemeteries Alive: Graveyards are resurging as green spaces for the public. Trade Magazine. Retrieved from https://urbanforestrysouth.org/resources/library/ttresources/cemeteries-alivegraveyards-are-resurging-as-green-spaces-for-the-public

Salmon, C. (2016). From Cemeteries to Luxurious Memorial Parks. Archipel.

(SDSN) Sustainable Development Solutions Network. (2019). Goal 11. Make cities and human settlements inclusive, safe, resilient and sustainable. Retrieved from https://indicators.report/goals/goal-11/

Tryjanowski, P., Morelli, F., Mikula, P., Krištín, A., Indykiewicz, P., Grzywaczewski, G., . . . Jerzak, L. (2017). Bird diversity in urban green space: A large-scale analysis of differences between parks and cemeteries in Central Europe. Urban Forestry \& Urban Greening, 27, 264-271. doi:https://doi.org/10.1016/j.ufug.2017.08.014 


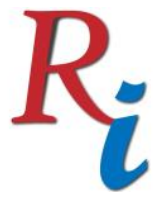

Asia Proceedings of Social Sciences

(APSS)

www.readersinsight.net/APSS

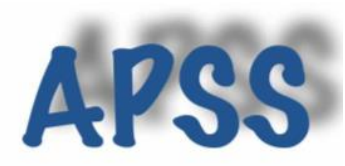

Author's Biography

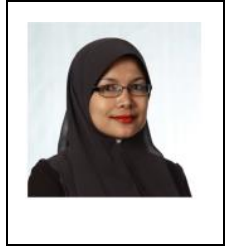

Dr. Putri Haryati is an Assistant Professor at the Department of Landscape Architecture, Kulliyyah of Architecture and Environmental Design (KAED), International Islamic University Malaysia (IIUM). She obtained her Doctorate from the University of Malaya, Malaysia in 2014. She is interested in the field of landscape architecture and recreational planning. More specifically, her works examine policies and regulations related to open space planning in Peninsular Malaysia. She is a Corporate Member of the Institut Landskap Arkitek Malaysia (ILAM) since 2016 and received an Honour Award for Landscape Research Award for the Malaysia Landscape Architecture Award 2018 organised by ILAM.

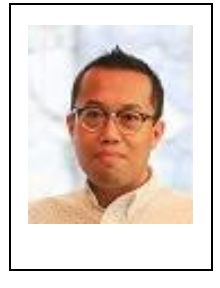

Dr. Mohamad Reza joined Universiti Sains Malaysia (USM) in 2015 after completing his Ph.D. from RMIT University in Melbourne, Australia. He is a lecturer in landscape architecture at the School of Housing, Building and Planning, USM specialising in cultural landscape, sustainable development, land use management and environmental planning. His research interests include dark tourism, democratic public space, deathscape, urban cemeteries, and material culture. He is a Corporate Member of the Institut Landskap Arkitek Malaysia (ILAM) since 2017

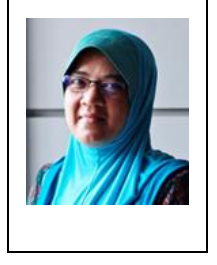

Dr. Azila Ahmad Sarkawi is an Associate Professor at the Department of Urban and Regional Planning, Kulliyyah of Architecture and Environmental Design, IIUM. She obtained her Doctorate from the Newcastle upon Tyne University, United Kingdom in 2006. Her areas of specializations are planning and environmental law and islamic planning principles. She is an associate member of the Malaysian Institute of Planners and received a Planning Scholar Award for Planning Excellence 2009 organised by the Malaysian Institute of Planners. 